UDC 616.342.018.25-091:616.5-001.17.:616.379-08.64:57.084.1

doi.org/10.32345/USMYJ.1(109).2019.35-47

\title{
Тимошенко Ірина Олексіївна
}

Старший викладач кафедри анатомії людини Національного медичного університету імені О.О. Богомольця, м. Київ, Україна

\section{СТРУКТУРНІ ОСОБЛИВОСТІ СЛИЗОВОЇ ОБОЛОНКИ ДВАНАДЦЯТИПАЛОЇ КИШКИ ЩУРІВ ПРИ ОПІКОВІЙ ТРАВМІ ШКІРИ ЗА УМОВ ЕКСПЕРИМЕНТАЛЬНОГО СТРЕПТОЗОТОЦИНІНДУКОВАНОГО ЦУКРОВОГО ДІАБЕТУ}

Анотація Робота присвячена вивченню структурних особливостей слизової оболонки дванадиятипалої кишки при опіковій травмі шкіри за умов експериментального стрептозотоииніндукованого иукрового діабету. Дослідження здійснене на лабораторних білих статевозрілих щурах-самиях масою 180-210 г. Групу контролю склали 21 інтактна тварина, I експериментальну групу склали 21 щур з експериментальною опіковою травмою шкіри, II експериментальну групу склали 21 щур без опіку шкіри з експериментальним стрептозотоциніндукованим діабетом, III експериментальну групу склали 21 щур з опіком икіри та експериментальним стрептозотоциніндукованим діабетом. Модель експериментального иукрового діабету відтворювали шляхом введення шурам стрептозоточину внутрішньоочеревенно одноразово в дозі 50 мг/кг. Термічне опікове пошкодження шкіри у щурів відповідало II - A-Б ступеню - дермального поверхневого опіку (за старою класифікачією III - А ступінь) загальною площуею 21-23\% поверхні тіла з розвитком опікового шоку. Для морфологічних досліджень було забрано відділ дванадиятипалої кишки, фрагменти якого обробляли загальноприйнятими методами світлової та електронної мікроскопї. Основними критеріями оцінки пошкодження слизової оболонки дванадиятипалої кишки стали результати дослідження щуоо порівняння гістологічних та ультраструктурних даних в динамиці через 7, 14, та 21 добу після опіку шкіри. Результати проведених досліджень показали зменшення кількості щільних контактів в інтестінальному епітеліальному бар'єрі слизової оболонки дванадиятипалої кишки щурів першої та третьої експериментальних груп та втрату упорядкованості (набуття певної хаотичності) їхньої локалізації у міру збільшення часу після опікової травми. В інтестінальному епітеліальному бар'єрі з'являються дефекти, які $\epsilon$ потенційними шляхами парацелюлярної транслокації патогенного вмісту дванадиятипалої кишки. Не виключно, щэо частина цьього інтестінального патогенного вмісту може бути транслокована $і$ через частково пошкоджені клітин. Свідченням останнього $\epsilon$ виявлена наявність мікробних тіл в цитоплазмі клітин з частково зруйнованою плазмолемою (але збереженими органелами та ядром). Адаптивним механізмом щзоо забезпечення репарації ушкоджених ентерочитів є селективна автофагія, яка виступає чинником рециклізачії матеріалу зруйнованих органел $і$ иитоплазматичного матриксу, спрямованого, в першу чергу, на підтримку життєздатності клітин. Ініціація автофагії асоційована з розвитком 6 ентероцитах стресу ендоплазматичного ретикулуму (ER-стресу). B ентероцитах дванадиятипалої кишки щурів третьої експериментальної групи ER-стрес відбувається настільки стрімко і супроводжується неухильним поширенням процесів деструкиї в клітині, що механізми автофагії не встигають спраџьовувати і більшість клітин гине. Таким чином, відсутність автофагійної реакиії $\epsilon$ маркером несприятливого спрямування перебігу післяопікових структурних змін в ентероцитах.

Ключові слова: опікова травма, стрептозотоциніндукований цукровий діабет, слизова оболонка дванадцятипалої кишки.

Cite as: Tymoshenko I.O. Structural mechanisms of disorders and adaptations of the inestinal epitelial barrier of the rat duodenal mucosa of rats during burn injury to the skin in the conditions of experimentally stretzotocotinindicated diabetes mellitus

Ukrainian scientific medical youth journal, issue, 1(109)- 2019 doi.org/10.32345/USMYJ.1(109).2019.35-47

35 
Вступ. Актуальною проблемою сучасної медицини є патогенез цукрового діабету та його ускладнень, до яких відноситься діабетична ентеропатія (Azpiroz, F., \& Malagelada, C., 2016;, Gotfried, J., et al., 2017; Ihana-Sugiyama, N., et al., 2016; Khoshbaten, M., et al., 2011; Rodrigues, M. L. C., \& Motta, M. E. F. A., 2012; Vaarala, O., et al., 2008). За оцінками Міжнародної федерації діабету у теперішній час у світі хворіє 425 мільйонів людей (IDF Diabetes Atlas). У той же час, у структурі загального травматизму в усьому світі (Smolle, C., et al., 2017) домінують опікові ураження. Важкі опіки викликають опікову хворобу, складовою якої є кишкова дисфункція (Galunko, G. M., 2017; Gotfried, J., et al., 2017; Netyukhailo, L. G., et al., 2011). Однак до цього часу вивчення структурних особливостей слизової оболонки дванадцятипалої кишки при опіковій травмі шкіри за умов іiї асоціації з цукровим діабетом не було предметом спеціальних досліджень.

Метою роботи було вивчення структурних особливостей слизової оболонки дванадцятипалої кишки щурів при опіковій травмі шкіри за умов експериментального стрептозотоциніндукованого цукрового діабету.

\section{Матеріали і методи.}

Дане дослідження проводилось на лабораторних білих статевозрілих щурах-самцях масою 180-210 г. Групу контролю склали 21 інтактна тварина, I експериментальну групу склали 21 щур з експериментальною опікової травмою шкіри, II експериментальну групу склали - 21 щур без опіку шкіри 3 експериментальним стрептозотоциніндукованим діабетом, III експериментальну групу склали - 21 щур 3 опіком шкіри та експериментальним стрептозотоциніндукованим діабетом. Усі процедури 3 лабораторними тваринами були проведені у відповідності до положень Свропейської конвенції щодо захисту хребетних тварин, яких використовують в експериментальних та інших наукових цілях (Страсбург, 1986); Директиви Ради Європи 86/609/EEC (1986 р.); Закону України № 3447 - IV «Про захист тварин від жорстокого поводження»; Загальних етичних принципів експериментів на тваринах, ухвалених Перишим національним конгресом України 3 біоетики (2001р.). Модель експериментального цукрового діабету (Natrus, L. V., et al., 2017) відтворювали шляхом введення щурам стрептозотоцину внутрішньоочеревенно одноразово в дозі 50 мг/кг, попередньо розчинивши його в $0,1 \mathrm{M}$ цитратному буферному розчині (pH-4,5). Контролем розвитку гіперглікемії в другій та третій екпериментальних групах був рівень глюкози в крові $24,24 \pm 0,79$ ммоль/л. В групі контролю 8,03 $\pm 0,4$ ммоль/л. У проведеному нами дослідженню опікову травму шкіри викликали у відповідності до поширеної серед дослідників базової моделі F. C. Regas, H.P. Ehrlich (Regas, F. C., \& Ehrlich, H. P., 1992), яка була дещо змінена і оптимізована I. Gunas et al (Gunas, I., Dovgan, I., \& Masur, O., 1997). При експериментальному моделюванню опіку шкіри, дві мідні пластинки у вигляді еліпсу витримували в воді при 100С 10 хвилин i, за умов ефірного наркозу, накладали одночасно симетрично на обидві поголені тильні частини тіла щурів з екзпозицією 10 секунд. Опікове пошкодження шкіри у щурів складало II -А-Б ступеня - дермального поверхневого опіку (за старою класифікацією III - A ступінь) загальною площею 21-23\% поверхні тіла з розвитком опікового шоку. Багатьма дослідниками (Cherkasov, E. V., 2012; Cherkasov, V. G., et al., 2015; Cherkasov, V. G., et al., 2015; Dzevulska, I. V., et al., 2018; Gunas, I. V., et al., 2018; Gunas, I. V., et al., 2014) доведено, що за умов застосування даної моделі експериментального опіку ініціюється розвиток опікової хвороби $з$ такими ii характерними ознаками як ендогенна інтоксикація, генералізована катаболічна реакція, системна запальна і апоптозна відповіді, поліорганна дисфункція. Для морфологічних досліджень було забрано відділ дванадцятипалої кишки, фрагменти якого обробляли загальноприйнятими методами світлової та електронної мікроскопії. Напівтонкі та ультратонкі зрізи з епоксидних блоків отримували на ультратомі LKB (Швеція). Ультратонкі зрізи після відповідного контрастування досліджували під електронним мікроскопом ПЕМ125K. Напівтонкі зрізи забарвлювали метиленовим синім та толуідиновим синім. Зрізи 3 парафінових блоків забарвлювали гематоксиліном-еозином. Основними критеріями оцінки пошкодження слизової оболонки дванадцятипалої кишки стали результати дослідження 
гістологічних та ультраструктурних даних в динамиці через 7, 14, та 21 добу після опіку шкіри. У вказані терміни щурам вводили однократно внутрішньоочеревенно велику дозу тіопенталу натрію і виводили із експерименту шляхом декапітації.

\section{Результати}

За даними електронної мікроскопії в ентероцитах слизової оболонки дванадцятипалої кишки тварин першої експериментальної групи через сім діб після опіку найбільш характерною ознакою структурних змін $є$ руйнація мікроворсинок щіточкової облямівки ентероцитів, а також зміни щільних контактів (tight junctions). Ці контакти чітко візуалізуються на електронних мікрофотографіях в локусах між апіколатеральними поверхнями сусідніх ентероцитів 3 щіточковою облямівкою тому, що зовнішні гідрофільні шари і глікокалікс суміжних плазмолем ніби зливаються в одній точці у суспільний електроннощільний шар, а скупчення тонофіламентів у прилеглій ділянці цитоплазми додає “точці” ще більшу електронну щільність. Звертає, на себе, увага деяка хаотичність розташування щільних контактів в епітеліальному моношарі (інтестінальному епітеліальному бар'єрі) дванадцятипалої кишки у щурів I екпериментальної групи, яка поглиблюється надалі із збільшенням часу після опіку. До складу інтестінального бар'єру дванадцятипалої кишки входять також келихоподібні клітини, які за умов норми мають цілісну плазмолему (яка, однак, не утворює щільних контактів 3 суміжними ентероцитами 3 щіточковою облямівкою) та численні пухирці, які містять секреторний матеріал середньої електронної щільності.

Поширеним явищем у цей часовий проміжок $є$ різноманітні ультраструктурні зміни ентероцитів на тлі набряку їхньої цитоплазми; від часткової втрати прикріплення рибосом до мембран канальців гранулярної ендоплазматичної сітки, до фрагментації цих канальців на окремі вакуолі; від реактивних змін мітохондрій (їхнього інтенсивного набухання, ділянкової фрагментації внутрішньої мембрани і крист), до повної руйнації органел, появи дефектів плазмолеми і каріолеми. В ділянках цитоплазми ентероцитів з частково втраченою щіточковою облямівкою розташовані округлі автофагосоми та автофаголізосоми різного розміру 3 гетероморфними електроннощільним вмістом.

Ультраструктурним свідченням початкового етапу автофагії $\epsilon$ групування ушкоджених клітинних органел в певних локусах цитоплазматичного матрикса та їхня секвестрація за допомогою концентричного охоплення характерною для автофагосом структурою - фагофором (подвійною ізолюючою мембраною). Надалі відбувається злиття автофагосом з лізосомами і утворення автофаголізосом з вмістом різного ступеня електронної щільності та різноманітної структурованості (що $є$ показником етапності та ефективності перетравлення секвестрованого матеріалу). Перетравлення вмісту автофаголізосом супроводжується руйнацією внутрішньої мембрани фагофора (за цих умов продукти перетравлення, ймовірно, поглинаються і засвоюються цитоплазмою ентероцита). Якщо частина матеріалу залишається неперетравленою, то відбувається трансформація автофаголізосоми у автофагійну вакуоль, яка спрямовується до плазмолеми апікальної ділянки ентероцита і вивільняє свій вміст назовні.

Через чотирнадцять діб після опіку в слизовій оболонці дванадцятипалій кишці у цитоплазмі багатьох ентероцитів 3 наявністю структурної ділянкової дефектності плазмолеми і каріолеми у сукупності з локальним пошкодженням цитоплазматичного матрикса (які, з огляду на їхню мінливість, ймовірно, можуть бути репаровані) виявлені ознаки підвищення функціональної активності органел (свідченням чого $\epsilon$ помірне розширення канальців гранулярної ендоплазматичної сітки, збільшення кількості рибосом, наявність полісом, агрегація неушкоджених мітохондрій, цілісність ядра). Рибосоми прикріплюються до мембран канальців гранулярної ендоплазматичної сітки нерівномірно (Рис. 1); залишаються різного розміру «оголені» ділянки та локуси їхнього накскрізного дефекту. У інших ентероцитах у цей час відбувається вакуолізація цитопазми у вигляді різного ступеня розширення канальців гранулярної ендоплазматичної сітки з просвітленням їхнього вмісту, вакуольна трансформація 
I.O. Tymoshenko Structural mechanisms of disorders and adaptations of the inestinal epitelial barrier of the rat duodenal mucosa of rats during burn injury to the skin in the conditions of experimentally stretzotocotinindicated diabetes mellitus

мітохондрій, які завершуються повною некротичною руйнацією і фрагментацією клітин 3 утворенням клітинного детриту.

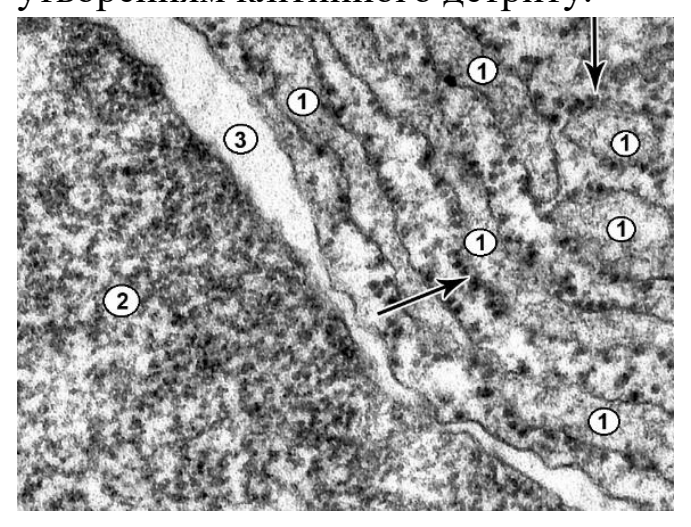

Рис.1 Нерівномірне розширення просвіту розгалужених канальців гранулярної ендоплазматичної сітки ентероцитів 3 щіточковою облямівкою в слизовій оболонці дванадцятипалої кишки щура першої експериментальної групи через 14 діб після опіку. Стрілочками відмічені прикріплені рибосоми. 1 - просвіт канальця гранулярної ендоплазматичної сітки; 2 - ядро ентероцита; 3 перинуклеарний простір. Електронна мікрофотографія. Зб. 52000.

Ділянки епітеліального моношару ентероцитів зі збереженною щіточковою облямівкою чергуються 3 ділянками вільними від щіточкової облямівки. До ентероцитів епітеліального моношару прилягають десквамовані клітини різного ступеня збереженості. В апікальній частині більшості ентероцитів з частково втраченою щіточковою облямівкою розміщувалися групи округлих автофагосом і автофаголізосом різного розміру $\mathrm{i}$ вмісту (Рис. 2).

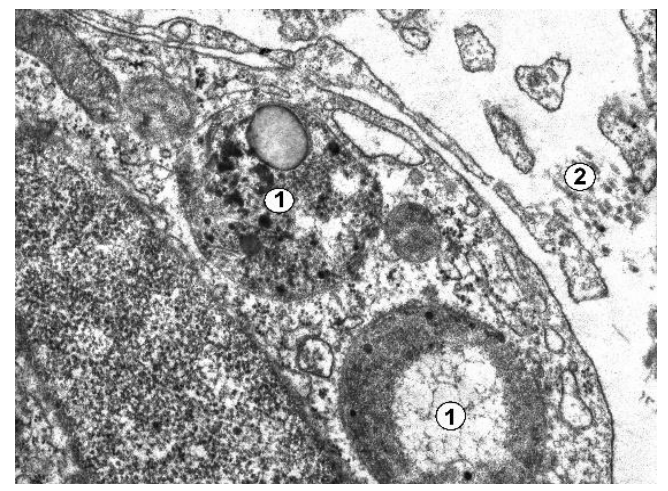

Рис. 2. Автофагосоми та автофаголізосоми (1) різного розміру в цитоплазмі ентероцита із втраченою щіточковою облямівкою в слизовій оболонці дванадцятипалої кишки щура першої експериментальної групи через 14 діб після опіку. 2 - залишки щіточкової облямівки. Електронна мікрофотографія Зб. 20000

У тварин першої експериментальної групи через двадцять одну добу після опіку морфологічно вогнищева атрофія слизової оболонки дванадцятипалої кишки проявлялась потовщенням i вкороченням ворсинок; місцями вони повністю були відсутні. Досить часто виявляли ерозії, які були результатом некрозу ентероцитів 3 щіточковою облямівкою та деструкцією келихоподібних клітин. На багатьох ділянках інтестінального епітеліального бар'єра (за рахунок втрати щільних контактів) суміжні ентероцити з щіточковою облямівкою відокремлювались один від одного, утворюючи розширені міжепітеліальні простори. В цитоплазмі деяких з означених ентероцитів були виявлені типові автофаголізосоми.

У щурів другої експериментальної групи через сім діб від початку експерименту при дослідженні слизової оболонки дванадцятипалої кишки в ентероцитах 3 щіточковою облямівкою був виявлений: набряк цитоплазми; частковий лізис мембран та вакуолізація канальців гранулярної ендоплазматичної сітки; різного ступеня набряк мітохондрій (проявом якого $\epsilon$ просвітлення міжмебранного просвіту i мітохондріального матриксу); часткова руйнація внутрішньої мітохондріальної мембрани, яка асоційована 3 фрагментацією мітохондріальних крист на окремі овальні пухирці. У випадках повної руйнації набряклих мітохондрій, зовнішня мітохондріальна мембрана розривається і залишки крист виходять 3 цитоплазми у вигляді пухирців. Частина ентероцитів 3 щіточковою облямівкою $\mathrm{i}$ келихоподібних клітин була у стані функціональної напруги, що проявлялось гіперплазією канальців гранулярної ендоплазматичної сітки, гіпертрофією мітохондрій, збільшення кількості полісом та рибосом. Пухка сполучна тканина строми ворсинок з ознаками набряку, містить численні фібробласти, колагенові волокна та лімфоцити. В деяких фібробластах цитоплазма $\epsilon$ вакуолізованою; в інших фібробластах відмічена маргинальна фестончаста конденсація хроматину в ядрах. Розміщені в цитоплазмі фібробластів мітохондрії мають просвітлений матрикс та редуковані кристи, а цистерин комплексу Гольджі та канальці гранулярної ендоплазматичної сітки розширені. 
I.O. Tymoshenko Structural mechanisms of disorders and adaptations of the inestinal epitelial barrier of the rat duodenal mucosa of rats during burn injury to the skin in the conditions of experimentally stretzotocotinindicated diabetes mellitus

У щурів другої експериментальної групи через чотирнадцять діб спостереження відмічена (Рис. 3) лейкоцитарна та лімфоцитарна інфільтрація набряклих ворсинок слизової

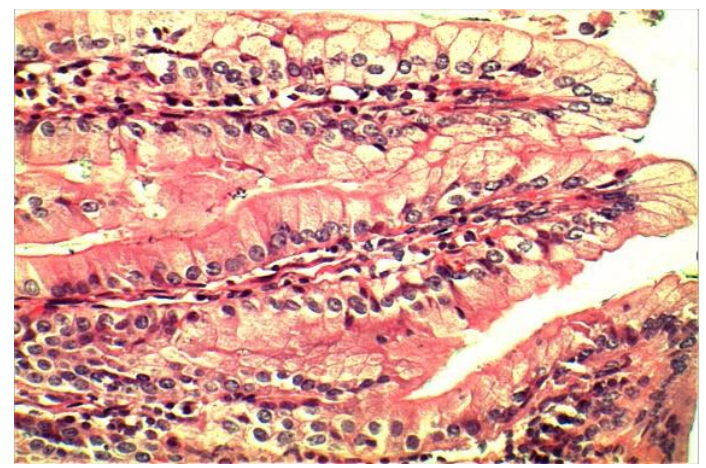
оболонки дванадцятипалої кишки.

Рис. 3. Лейкоцитарна та лімфоцитарна інфільтрація набряклих ворсинок слизової оболонки дванадцятипалої кишки щура другої експериментальної групи через 14 діб після початку експерименту. Мікрофотографія. Забарвлення гематоксиліном та еозином. 3б. 200

За даними електронної мікроскопії цитоплазма частини ентероцитів 3 щіточковою облямівкою була вакуолізована, мітохондрії набряклі, більшість мітохондріальних крист зруйнована; в інших ентероцитах 3 щіточковою облямівкою цитоплазма виглядала гіперхромною, а їхні ядра містили конденсований гіперхромний хроматин. Відмічені появи гетероморфності мітохондрій; серед великих та середніх за розміром мітохондрій типової будови локалізовані менші за розміром гіперхромні мітохондрії, які іноді щільно контактують 3 великими мітохондріями, що мають характерні пальцеподібні вип'ячувань («бруньки росту»?). Прилегла до ентероцитів базальна мембрана має мінливу структурну організацію, проявом якої $\epsilon$ чергування різних за протяжністю зон іiі розпушення і просвітлення із зонами іiї потовщення та ущільнення. В багатьох ентероцитах мікроворсинки щіточкової облямівки були коротшими, втрачали упорядковану орієнтацією, а деякі з них руйнувалися і накопичувалися у складі клітинного детриту у інтестінальному просвіті. В цих ентероцитах цистерни комплексу Гольджі та канальці гранулярної ендоплазматичної сітки були частково фрагментованими, втрачали прикріпленні до їхньої мембрани рибосоми та формували різні за розміром вакуолі.

У щурів другої експериментальної групи через двадцять одну добу спостереження при електронномікроскопічному дослідженні відмічене продовження експансії лейкоцитарної

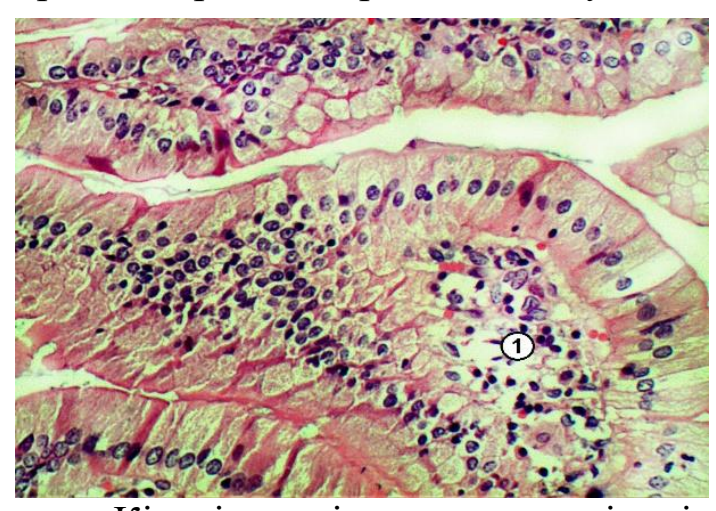
інфільтрації (Рис. 4) в набряклих ворсинках слизової оболонки дванадцятипалої кишки. В деяких ентероцитах 3 щіточковою облямівкою відмічене переважання деструктивних процесів в усіх мембранних органелах над поновлювальними процесами.

Рис. 4. Лейкоцитарна та ліфмфоцитарна інфільтрація набряклих ворсинок слизової оболонки дванадцятипалої кишки щура другої експериментальної групи через 21 добу після початку експерименту. 1 - осередок некрозу. Мікрофотографія.

Забарвлення гематоксиліном та еозином. Зб. 200

Кількість щільних контактів між епітеліоцитами зменшуються, а міжклітинні простори розширюються. Частина ентероцитів повністю втрачає міжклітинні контакти та клітинноматриксні зв'язки і відшаровується від базальної мембрани. Ентероцити відрізняються один від одного різною електронною щільністю цитоплазми та кількісним представництвом органел. Поруч з ентероцитами, в яких численні, заповненні електроннощільним вмістом, розгалужені

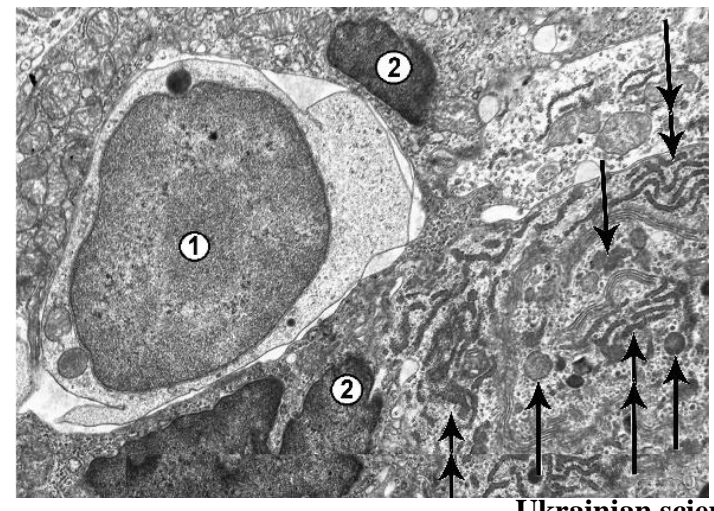
канальці гранулярної ендоплазматичної сітки асоційовані з автофагосомами та автофаголізосомами різних розмірів і форми (Рис. 5), розташовані ентероцити 3 невиразною гранулярною ендоплазматичною сіткою, без автофігосом і без автофаголізосом.

Рис. 5. Лімфоцит мігрує через розширений міжепітеліальний простір в слизовій оболонці дванадцятипалої кишки щура другої експериментальної групи черз 14 діб після

Ukrainian scientific medical youth journal, 2019, Issue 1(109)

http://mmj.nmuofficial.com 
початку експерименту. Одинарними стрілочками відмічені автофагосоми і автофаголізосоми різних розмірів і форми; Подвійними стрілочками відмічені наповнені електроннощільним вмістом канальці розгалуженої гранулярної ендоплазматичної сітки. 1 - ядро лімфоцита; 2 - ядро епітеліоцита. Електронна мікрофотографія $3 б$. 20000

Типовим атрибутом такої ультраструктурної композиції $є$ наявність міжепітеліальних лімфоцитів. У переважній частині келихоподібних клітин засвідчений лізис мембран секреторних гранул, вміст яких вивільнюється через дефекти плазмолеми клітини назовні. Ці зміни поєднуються 3 деструкцією мембран канальців гранулярної ендоплазматичної сітки $\mathrm{i}$ мітохондрій. Прилегла до епітеліоцитів базальна мембрана візуально є потовщеною і зберігає свою цілісність, архітектонічно необхідну для подільшого відновлення епітеліального моношару як компоненту інтестінального епітеліального бар'єру.

При гістологічному дослідженні слизової оболонки дванадцятипалої кишки щурів третьої експериментальної групи через сім діб від початку експерименту виявили ознаки деформації та дискомплексації ворсинок, що призводило до їхнього загального поліморфізму. Ці процеси перебудови кишкових ворсинок відбувалися на тлі набряку пухкої сполучної тканини власної пластинки та їхньої лейкоцитарної інфільтрації. На верхівках ворсинок розповсюдженим явищем $є$ десквамація ентероцитів 3 щіточковою облямівкою. Відмічається збільшення (у порівнянні з нормою) кількості келихоподібних клітин. Просвіти кишкових крипт розширені. В клітинах Панета цитоплазма набрякла, кількість типових ацидофільних гранул зменшена у порівнянні з нормою. Кровоносні судини слизової оболонки мають розширений просвіт, для венозних кровоносних судин характерним $є$ повнокрів'я та набряк паравазального інтерстицію. У багатьох локусах значного паравазального набряку виявлені вогнища діапедезних крововиловів та лейкоцитарних інфільтратів. Центральні лімфатичні судини ворсинок переповнені лімфою, що сприяє значному розширенню судинного просвіту.

Результати електронномікроскопічного дослідження підтверджують дані світлової мікроскопії і свідчать, що у тварин третьої експериментальної групи через сім діб після опіку розповсюдженим є субтотальний некроз ентероцитів 3 щіточковою облямівкою, коли при збереженні частини цитоплазми з неушкодженою облямівкою, окрема ділянка клітини підлягає некротичній дегенерації, а утворений клітинний детрит з мікроворсинками облямівки потрапляє у інтестінальний простір. Деструкції підлягає більшість келихоподібних клітин, які після накопичення секрету повністю руйнуються. Якщо це відбувається в криптах, то залишки келихоподібних клітин включаються до вмісту крипт і (разом з рештками ентероцитів) деформують їхній просвіт.

За даними світлової мікроскопії через чотирнадцять діб від початку експерименту у тварин третьої експериментальної групи типовими є прояви дискомплексації, деформації та поліморфізму кишкових ворсинок слизової оболонки дванадцятипалої кишки. Доволі чисельними $є$ ділянки десквамації ентероцитів 3 щіточковою облямівкою (за рахунок чого моношар епітеліоцитів на ворсинках втрачав необхідну суцільність). Особливо типовим це явище було характерним для розгалужених кишкових ворсинок і втрачало свою типовість для вкорочених кишкових ворсинок. Епітеліальний моношар покриття ворсинок виглядає сплощеним, ядра епітеліоцитів зміщені від базального полюса до центру клітини. Між епітеліоцитами розміщуються поодинокі лімфоцити. Чисельність келихоподібних клітин на кишкових ворсинках є більшою, ніж у інтактних щурів. Глибина кишкових крипт зменшена у порівнянні з нормою, їхні просвіти розширені та заповнені еозинофільним вмістом. Чисельні келихоподібні клітини наповнені слизовим секретом. Ближче до дна крипт у епітеліальному моношарі виявлені малодиференційовані клітини на різних стадіях мітозу. Цитоплазма ентероцитів 3 щіточковою облямівкою виглядає набряклою, базальна орієнтація ядер $\epsilon$ порушеною. Сполучна тканина власної пластинки слизової оболонки дванадцятипалої кишки набрякла із зонами вогнещевих діапедезних крововиловів, що локалізовані біля кровоносних капілярів і венул 3 явищами стазу еритроцитів в розширених судинних просвітах. В 
I.O. Tymoshenko Structural mechanisms of disorders and adaptations of the inestinal epitelial barrier of the rat duodenal mucosa of rats during burn injury to the skin in the conditions of experimentally stretzotocotinindicated diabetes mellitus

сполучнотканинній стромі кишкових ворсинках серед фібробластів розміщувалися нейтрофільні лейкоцити, лімфоцити, плазмоцити, макрофаги, а також поодинокі тканинні базофіли і еозинофільні лейкоцити.

Детальне електронномікроскопічне дослідження дозволило уточнити, що через чотирнадцять діб після опіку в слизовій оболонці дванадцятипалої кишки тварин третьої експериментальної групи ентероцити на певних ділянках епітеліального моношару підлягають повному некротичному розпаду. В цих ділянках базальна мембрана стає “оголеною”. Вона $\epsilon$ доволі гарно збереженою i, навіть, на окремих ділянках є дещо потовщеною у порівнянні 3 такою за умов норми (у контрольної групи щурів), але й в ній є наскрізні дефекти (Рис. 6).

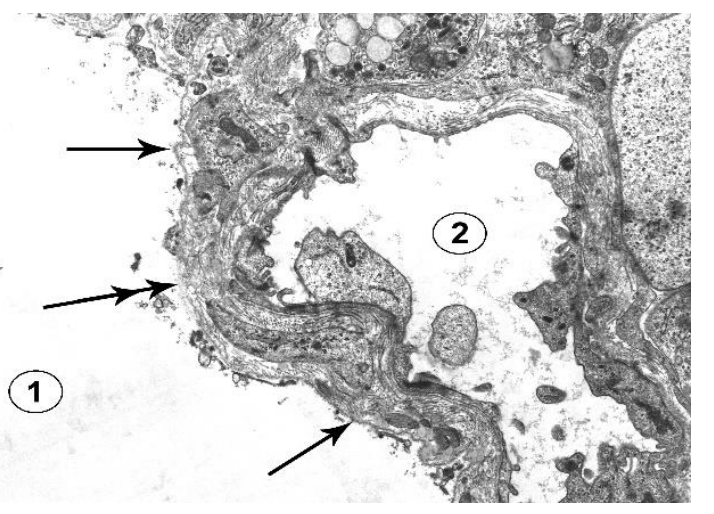

\begin{abstract}
Рис. 6. Некроз ентероцитів слизової оболонки дванадцятипалої кишки щура третьої експериментальної групи через 14 діб після опіку. Одинарними стрілочками відмічена “оголена" базальна мембрана епітеліального моношару; Подвійної стрілочкою відмічений наскрізний дефект (відсутність) базальної мембрани. 1 - інтестінальний просвіт; 2 - просвіт кровоносного капіляра. Електронна мікрофотографія
\end{abstract} 3б. 15000

\begin{tabular}{ccr} 
Описані & вище & \multicolumn{1}{c}{ структурні } \\
супроводжуються & деформацією i & руйнацією
\end{tabular} ворсинок слизової оболонки дванадцятипалої кишки. Ворсинки втрачають типову листоподібну форму, часто набувають “покрученого" вигляду, з'являються ниткоподібні ворсинки, що оточені групами десквамованих ентероцитів і клітинним детритом.

При гістологічному дослідженні слизової оболонки дванадцятипалої кишки щурів третьої експериментальної групи через двадцять одну добу від початку експерименту зберігалися явища деформації кишкових ворсинок, які $є$ проявом їхньої дискомплексації (у сенсі порушення правильного співвідношення клітинних елементів), що взагалі призводить до виразного поліморфізму кишкових ворсинок (крайнім проявом якого $є$ поява кишкових ворсинок з різко відмінними ознаками). Останнє може бути свідченням (відміченої і у попередні терміни перебігу ентеропатії) різноманітності структурних проявів патологічного процесу, обумовленою асоційованою дією чинників опікової хвороби та цукрового діабету (ця асоційована дія виглядає не як проста сумація структурних ефектів, а як більш складний процес їхньої трансформації).

Епітелальний покрив кишкових ворсинок має чисельні ділянки десквамації епітеліоцитів не тільки на верхівках ворсинок, але й поза ними. Ентероцити із збереженою щіточковою облямівкою сплощені з порушеною упорядкованістю базальної орієнтації ядер. В інтестінальному просвіті розташовані частково збережені злущені ентероцити та клітинний детрит. У ворсинках і криптах слизової оболонки достатньо великою $\epsilon$ чисельність келихоподібних клітин із зруйнованою апікальною цитоплазмою. Строма власної пластинки кишкових ворсинок інфільтрована нейтрофільними лейкоцитами i виглядає набряклою. Відмічене застійне повнокрів'я в судинах гемомікроциркуляторного русла та значне розширення просвітів центральних лімфатичних судин в кишкових ворсинках.

Кишкові ворсинки втрачають свою типову цитоархітектоніку i мають вигляд гроноподібних (а іноді грибоподібних) конгломератів ентероцитів різного ступеня структурної збереженості. На більшій своїй протяжності інтестінальний епітеліальний бар'єр втрачає цілісність клітинної складової при частковій збереженості базальної мембрани (перше відбувається як за рахунок некрозу ентероцитів з щіточковою облямівкою, так і за рахунок повної деструкції келихоподібних клітин). У всіх випадках в інтестінальному епітеліальному бар'єрі з'являються дефекти, які є потенційними шляхами парацелюлярної транслокації патогенного вмісту дванадцятипалої кишки. Не виключно, що частина цього інтестінального патогенного вмісту може бути транслокована і через частково пошкоджені клітин. Свідченням 
I.O. Tymoshenko Structural mechanisms of disorders and adaptations of the inestinal epitelial barrier of the rat duodenal mucosa of rats during burn injury to the skin in the conditions of experimentally stretzotocotinindicated diabetes mellitus

останнього $є$ виявлена наявність мікробних тіл в цитоплазмі клітин з частково зруйнованою плазмолемою (але збереженими органелами та ядром).

\section{Обговорення.}

Цукровий діабет і пов’язані 3 ним ускладнення (зокрема діабетична ентеропатія) стають усе більше розповсюдженими. Автори останньої (за часом публікації) наукової оглядової статті "Diabets and the small intestine" (Gotfried, J., et al., 2017) засвідчують, що новітні наукові результати є перспективними, але усе ще існує велика потреба у подальших дослідженнях патогенезу діабетичної ентеропатії.

Багато невирішених проблем залишається щодо ролі структурних і функціональних змін інтестінального епітеліального бар'єра тонкої кишки у патогенезі опікової хвороби. А також, зокрема, щодо дисфункції за умов опіку інтестінального епітеліального бар'єра (Costantini, T. W., et al., 2009; Huang, Y., et al., 2018). Одержані нами дані свідчать про структурні прояви порушення бар'єра (руйнація щільних міжепітеліальних контактів, зникнення інтердигітацій цитоплазматичних відростків сусідніх ентероцитів) при опіковій травмі шкіри за умов експериментального стрептозотоциніндукованого діабету. Крім того, нами підтверджені дані (Huang Ya. et al., 2018) щодо участі автофагійних процесів у розвитку постопікової структурної дезорганізації інтестінального епітеліального бар'єра, але на відміну від зазначених авторів, ми розглядаємо їх як прояв адаптивної реакції.

Отримані нами дані щодо структурних перетворень канальців гранулярної ендоплазматичної сітки та автофагії в ентероцитах слизової оболонки дванадцятипалої кишки щурів 3 опіком шкіри найбільше відповідають концепсії (Schröder, M., 2008) стресу ендоплазматичного ретикулуму (endoplasmic reticulum stress aбo ER- стресу), який , зазвичай, асоційований $з$ автофагією (Huang, Y., et al., 2018). Гранулярна ендоплазматична сітка, за сучасними уявленнями, є надзвичайно динамічною органелою, яка забезпечує високу точність контролю якості синтезу, дозрівання та транспорту білків (Schwarz, D. S., \& Blower, M. D., 2016). В клітині білки синтезуються у вільних рибосомах, які можуть приєднуватися (у відповідь на розпізнавання мембранного сигналу у належності до N-сигнальної послідовності) до поверхні мембран канальців гранулярної ендоплазматичної сітки, де синтезується багато білків, що мають пройти сортування і переміщення до певних ділянок клітини (інтегральні мембранні білки; білки органел; білки, що призначені для секреції). Лінейні ланцюги амінокислот розміщуються в порожнині канальців гранулярної ендоплазматичної сітки, де згодом піддаються пострансляційній модифікації і згортаються (folding of proteins) до нативної конфігурації, набуваючи необхідну тривимірну структуру. Ендоплазматична стіка має забезпечити дуже точний і високоякісний контроль за дозріванням і згортанням мембранних і секреторних білків для того, щоб лише правильно згорнуті білки мали змогу потрапити за межі канальців ендоплазматичної сітки, а незгорнуті чи неправильно згорнуті залишалися в канальцях ендоплазматичної сітки і були знищені.

За умов дії різноманітних чинників (а також при зміні внутрішньоклітинного та позаклітинного гомеостазу), які призводять до порушень згортання і дозрівання білків в канальцях ендоплазматичної сітки, клітина реагує (Schröder, M., 2008) на незгорнуті чи неправильно згорнуті білки стресом ендоплазматичного ретикулума (ER- стресом). Індукція ER- стресу не лише призводить до посиленної деградації незгорнутих чи неправильно згорнутих білків, але й сприяє реорганізації метаболічних процесів у клітині для забезпечення іiі виживання або смерті у разі прогресії незворотних змін (Sano, R., \& Reed, J. C., 2013). Для відновлення внутрішньоклітинної гомеостатичної функції за умов ER- стресу спрацьовує розгалужений сигнальний каскад або гарно оркестрований («orchestrating») сигнальний шлях, який (Schröder, M., \& Kaufman, R. J., 2005). дістав назву «відповідь на незгорнуті білки» (англ. unfolded protein response, UPR). У ссавців складовими відповіді на незгорнуті білки є три основні спеціалізовані сенсорно-сигнальні системи, ланцюгова дія яких починається з просвіту канальців ендоплазматичної сітки (де розміщена їхня сенсорна частина) і досягає цитоплазми $\mathrm{i}$ ядра. Внаслідок відповіді на незгорнуті білки трансляції більшості білків пригнічуються (для 
зменшення навантаження на ендоплазматичну сітку); винятком є тільки ті білки, що сприяють подоланню ER- стресу: шаперони; трансмітери амінокислот; білки ERAD (ER-associated degradation), що необхідні для деградації незгорнутих білків. Таким чином, сценарій розвитку відповіді на незгорнуті білки передбачає досягнення послідовного вирішення конкретних завдань щодо відновлення нормального функціонування клітини шляхом: 1) зупинки або обмеження трансляції білків; 2) деградації неправильно складених білків; 3) активації сигнальних шляхів, що призводять до збільшення виробництва шаперонів, які приймають участь у складанні білків. При найгіршому розвитку сценарія (якщо зазначені завдання не будуть вирішені і не вдасться своєчасно відновити гомеостаз) відповідь на незгорнуті білки може завершитися смертю клітини (Sano, R., \& Reed, J. C., 2013; Schröder, M., \& Kaufman, R. J., 2005).

Що стосується автофагії, то визначено (Cherkasov, E. V., 2012), що процес автофагії є типовою післяопіковою реакцією епітеліоретикулоцитів тимуса. Автофагія може бути джерелом додаткового (аварійного) живлення клітин в умовах характерного для опікової хвороби гіперметаболізму і його складової - гіперкатаболізму. При локальному характері розвитку, автофагія забезпечує ізоляцію і видалення 3 клітин ушкоджених органел i цитоплазматичного матриксу, а також сприяє адаптивній перебудові клітини (вилучення елементів дефектних структур та застосування переробленого у автофаголізосомах матеріалу для відновлення структурної спроможності наявної частини неушкоджених органел). Адаптивність автофагії полягає в тому, що репарована частина клітини може бути не тільки індентичною (за структурним забезпеченням) до вилученої, але й більш придатною (у кількісному і якісному виразі) для функціонування за умов негативних впливів чинників опікової хвороби.

Приймаючи до уваги наведені вище дані наукової літератури слід зауважити, що виконані нами ультраструктурні дослідження дають підстави вважати, що розвиток ER- стресу та асоційованої з ним автофагії в епітелії слизової оболонки дванадцятипалої кишки при опіковій травмі шкіри (тварини першої експериментальної групи) можуть відбуватися у наступній послідовності: 1) розширення i розгалуження канальців гранулярної ендоплазматичної сітки, переповнених електроннощільним вмістом (що свідчить про адаптивне напруження функціонування гранулярної ендоплазматичної сітки, яке спрямоване на продукцію білків); 2) втрата частиною рибосом прикріплення до мембран канальців гранулярної ендоплазматичної сітки (що може свідчити про зниження рівня продукції білків, у тому числі структуроутворюючих білків щільних контактів); 3) сегментація канальців гранулярної ендоплазматичної сітки на вакуолі (що свідчить про дизадаптацію та про можливу продукцію спотвореною органелою невірно зібраних та модифікованих білків); 4) поява автофагосом і автофаголізосом (що може свідчити про суттєві зміни внутрішньоклітинного білкового гомеостазу і спробу їх зневілювати шляхом знищення спотвореного матеріалу в автофаголізосомах).

Визначені нами, як складові структурного виразу ER- стресу, розширенння просвіту i розгалуження канальців гранулярної ендоплазматичної сітки можуть вірогідно свідчити про функціональну напруженість щодо продукції білків, які сприяють подоланню стресу (Schröder, M., 2008; Schröder, M., \& Kaufman, R. J., 2005). Проте, можлива і інша трактовка подібних трансформацій канальців гранулярної ендоплазматичної сітки при ER- стресі. Зокрема, (Bernales, S., McDonald, K. L., \& Walter, P. 2006) у дріжджів засвідчили асоціацію автофагії $з$ ER- стресом і показали, що клітини за умов індукції відповіді на незгорнуті білки розширяють як набір молекулярних механізмів, так і простір, призначений для згортання білків, щоб задовольнити потреби нового фізіологічного стану, в якому білки залишаються у просвіті канальців гранулярної ендоплазматичної сітки (поки вони не будуть належним чином складені або не піддадуться деградації). Розгалуження і розширення просвіту канальців гранулярної ендоплазматисної сітки дозволяють знизити концентрацію незгорнутих білків, а з іншого боку створюють умови (часові і просторові) для більш чіткої дії механізмів розпізнавання невірно 
складених білків і подальшого звільнення клітини від них шляхом залучення системи ERAD (ER-associated degradation).

Ще раз підкреслюємо, що нами засвідчена суттєва різниця у перебігу ER- стресу в ентероцитах щурів різних експериментальних груп. В слизовій оболонці дванадцятипалої кишки щурів третьої експериментальної групи (за умов поєднання експериментальної опікової травми шкіри 3 експериментальним цукровим діабетом) ER- стрес відбувається настільки стрімко і супроводжується неухильним поширенням (від локального до осередкового і надалі до субтотального і до тотального) деструкції плазмолеми, каріолеми і критичної кількості мембранних органел, що механізми автофагії не встигають спрацювати, епітеліоцити накопичують неутілізованний спотворенний матеріал і гинуть шляхом некрозу. Найбільш чутливими до ER- стресу є, як нами виявлено, келихоподібні клітини, які серед решти ентероцитів гинуть шляхом некрозу першочергово. Логічним буде висновок, що відсутність асоціації ER- стресу 3 автофагією є негативним маркером втрати гальмівного за сутністю механізму, який за цих умов не перериває каскадний характер молекулярних процесів за участю неутілізованого спотвореного матеріалу, що призводить до незворотних структурних змін в клітинах. Описані нами морфологічні події $є$ в край несприятливими щодо забезпечення захисної функції інтестінального епітеліального бар'єру, наслідком втрати якої може бути складна відповідь усього організму у вигляді погіршення загального стану опеченого i ускладнення перебігу супутнього захворювання.

За наведених вище міркувань, люди хворі на цукровий діабет мають увійти до групи ризику і повинні бути убезпечені від можливості отримати опікову травму на роботі чи у побуті. При опіковому травмувані хворих на цукровий діабет слід зважати не тільки на розвиток ентеропатії, а й на такі наслідки порушення інтестінального епітеліального бар'єру як транслокація мікробіоти та іншого внутрішньопросвітного інтестінального вмісту токсичної та імуногенної дії (що погіршує перебіг цукрового діабету і додає до розвитку його ускладнень багато негативних чинників).

Перспективи подальших досліджень у цьому напрямку пов'язанні з вивченням впливу на дванадцятипалу кишку опечених 3 цукровим діабетом препаратів, що зменшують інтоксикацію організму і рівень цукру в крові.

\section{Висновки}

Результати проведених досліджень показали, зменшення кількості щільних контактів в інтестінальному епітеліальному бар'єрі слизової оболонки дванадцятипалої кишки щурів першої та третьої експериментальних груп та втрату упорядкованості (набуття певної хаотичності) їхньої локалізації у міру збільшення часу після опікової травми. В інтестінальному епітеліальному бар'єрі з'являються дефекти, які є потенційними шляхами парацелюлярної транслокації патогенного вмісту дванадцятипалої кишки. Не виключно, що частина цього інтестінального патогенного вмісту може бути транслокована і через частково пошкоджені клітин. Свідченням останнього $є$ виявлена наявність мікробних тіл в цитоплазмі клітин 3 частково зруйнованою плазмолемою (але збереженими органелами та ядром). Адаптивним механізмом щодо забезпечення репарації ушкоджених ентероцитів є селективна автофагія, яка виступає чинником рециклізації матеріалу зруйнованих органел і цитоплазматичного матриксу, спрямованого, в першу чергу, на підтримку життєздатності клітин. Ініціація автофагії асоційована 3 розвитком в ентероцитах стресу ендоплазматичного ретикулуму (ER-cтpec). B ентероцитах дванадцятипалої кишки щурів третьої експериментальної групи ER-стрес відбувається настільки стрімко і супроводжується неухильним поширенням процесів деструкції в клітині, що механізми автофагії не встигають спрацьовувати і більшість клітин гине. Таким чином, відсутність автофагійної реакції є маркером несприятливого спрямування перебігу післяопікових структурних змін в ентероцитах.

\section{ЛІТЕРАТУРА}

Anding, A. L., \& Baehrecke, E. H. (2015). Autophagy in cell life and cell death. In Current topics in developmental biology (Vol. 114, pp. 67-91). Academic Press. 
I.O. Tymoshenko Structural mechanisms of disorders and adaptations of the inestinal epitelial barrier of the rat duodenal mucosa of rats during burn injury to the skin in the conditions of experimentally stretzotocotinindicated diabetes mellitus

Azpiroz, F., \& Malagelada, C. (2016). Diabetic neuropathy in the gut: pathogenesis and diagnosis. Diabetologia, 59(3), 404-408.

Blandino, G., Inturri, R., Lazzara, F., Di Rosa, M., \& Malaguarnera, L. (2016). Impact of gut microbiota on diabetes mellitus. Diabetes \& metabolism, 42(5), 303-315.

Cherkasov, V. G., Kovalchuk, A. I., Dzevulskaya, I. V., Malikov, A.V., Lakhtadyr, T.V., \& Matkivskaya, R. M. (2015). Structural transformations in the internal organs with infusion therapy for burn disease. Medical Science of Ukraine, (11, № 3-4), 4-11.

Cherkasov, V. G., Kovalchuk, A. I., Dzevulskaya, I. V., \& Cherkasov, E. V. (2015). Evaluation of the effect of infusion of composite hyperosmolar solutions on the structure of neuroimmunoendocrine system organs in burn diseas. European International Journal of Science and Technology, 4(9), 51-61.

Costantini, T. W., Loomis, W. H., Putnam, J. G., Drusinsky, D., Deree, J., Choi, S., ... \& Coimbra, R. (2009). Burninduced gut barrier injury is attenuated by phosphodiesterase inhibition: effects on tight junction structural proteins. Shock (Augusta, Ga.), 31(4), 416.

Dzevulska, I. V., Kovalchuk, O. I., Cherkasov, E. V., Majewskyi, O. Y., Shevchuk, Y. G., Pastukhova, V. A., \& Kyselova, T. M. (2018). Influence of lactoproteinum solution with sorbitol on dna content of cells of endocrine glands on the background of skin burn in rats. World of medicine and biology, 14(64), 033-039.

Elshaer, D., \& Begun, J. (2017, January). The role of barrier function, autophagy, and cytokines in maintaining intestinal homeostasis. In Seminars in cell \& developmental biology (Vol. 61, pp. 51-59). Academic Press.

Evers, L. H., Bhavsar, D., \& Mailänder, P. (2010). The biology of burn injury. Experimental dermatology, 19(9), 777-783.

Galunko, G. M. (2017). Histological changes in the small intestine in the advanced stages of burn disease. World of Medicine and Biology, (3), 90-96.

Gotfried, J., Priest, S., \& Schey, R. (2017). Diabetes and the small intestine. Current treatment options in gastroenterology, 15(4), 490-507.

Gunas, I., Dovgan, I., \& Masur, O. (1997). Method of thermal burn trauma correction by means of cryoinfluence. Verhandlungen der Anatomischen Gesellschaft, 92, 105.

Gunas, I. V., Guminskiy, Y. I., Ocheretn, N. P., Lysenko, D. A., Kovalchuk, O. I., Dzevulska, I. V., \& Cherkasov, E. V. (2018). Indicators cell cycle and dna fragmentation of spleen cells in early terms after thrmal burns of skin at the background of introduction $0.9 \% \mathrm{NaCl}$ solution. World of Medicine and Biology, 14(63), 116-120.

Gunas, I. V., Kovalchuk, O. I., Cherkasov, V. G., \& Dzevulskaya, I. V. (2014). Structural aspects of the organs adaptive changes of the neuroimundocrine system in the treatment of burn disease with combined hyperosmolar solutions. Galician Medical Herald, 21(2), 21-26.

Huang, Y., Feng, Y., Wang, Y., Wang, P., Wang, F., \& Ren, H. (2018). Severe burn-induced intestinal epithelial barrier dysfunction is associated with endoplasmic reticulum stress and autophagy in mice. Frontiers in physiology, $9,441$.

Ihana-Sugiyama, N., Nagata, N., Yamamoto-Honda, R., Izawa, E., Kajio, H., Shimbo, T., ... \& Noda, M. (2016). Constipation, hard stools, fecal urgency, and incomplete evacuation, but not diarrhea is associated with diabetes and its related factors. World journal of gastroenterology, 22(11), 3252.

Khoshbaten, M., Madad, L., Baladast, M., Mohammadi, M., \& Aliasgarzadeh, A. (2011). Gastrointestinal signs and symptoms among persons with diabetes mellitus. Gastroenterology and hepatology from bed to bench, 4(4), 219.

Knip, M., \& Siljander, H. (2016). The role of the intestinal microbiota in type 1 diabetes mellitus. Nature Reviews Endocrinology, 12(3), 154.

Natrus, L. V., Ryzhko, I. N., Kozak, A. I., Kryvosheieva, O. I., \& Stechenko, L. A. (2017). Ultrastructural base of the connective tissue skin'cells interactions at burn injury in the hyperglycemic white rats. World of Medicine and Biology, 13(62), 157-162.

Netyukhailo, L. G., Kharchnko, S. V., \& Kostenko, A. G. (2011). Pathogenesis of burn disease (in 2 parts). Svit Med. Biol, (1), 127-135.

Nighot, P. K., Hu, C. A. A., \& Ma, T. Y. (2015). Autophagy enhances intestinal epithelial tight junction barrier function by targeting claudin-2 protein degradation. Journal of Biological Chemistry, 290(11), 7234-7246.

Pasternak, A., Szura, M., Gil, K., \& Matyja, A. (2016). Interstitial cells of Cajal-systematic review. Folia morphologica, 75(3), 281-286.

Regas, F. C., \& Ehrlich, H. P. (1992). Elucidating the vascular response to burns with a new rat model. The Journal of trauma, 32(5), 557-563.

Rodrigues, M. L. C., \& Motta, M. E. F. A. (2012). Mechanisms and factors associated with gastrointestinal symptoms in patients with diabetes mellitus. Jornal de pediatria, 88(1), 17-24.

Smolle, C., Cambiaso-Daniel, J., Forbes, A. A., Wurzer, P., Hundeshagen, G., Branski, L. K., ... \& Kamolz, L. P. (2017). Recent trends in burn epidemiology worldwide: A systematic review. Burns, 43(2), 249-257.

Turner, J. R. (2009). Intestinal mucosal barrier function in health and disease. Nature reviews immunology, 9(11), 799. 
I.O. Tymoshenko Structural mechanisms of disorders and adaptations of the inestinal epitelial barrier of the rat duodenal mucosa of rats during burn injury to the skin in the conditions of experimentally stretzotocotinindicated diabetes mellitus

Vaarala, O., Atkinson, M. A., \& Neu, J. (2008). The "perfect storm" for type 1 diabetes: the complex interplay between intestinal microbiota, gut permeability, and mucosal immunity. Diabetes, 57(10), 2555-2562. 
I.O. Tymoshenko Structural mechanisms of disorders and adaptations of the inestinal epitelial barrier of the rat duodenal mucosa of rats during burn injury to the skin in the conditions of experimentally stretzotocotinindicated diabetes mellitus

\title{
STRUCTURAL CHARACTERISTICS OF THE RAT DUODENAL MUCOSA DURING BURN INJURY TO THE SKIN UNDER THE CONDITIONS OF EXPERIMENTAL STREPTOZOTOCININ-INDUCED DIABETES MELLITUS
}

\section{Tymoshenko Irina Alekseevna \\ Assistant at Department of Human Anatomy Bogomolets National Medical University.}

\begin{abstract}
The work is devoted to the study of structural features of the mucous membrane of the duodenum in case of burn injury to the skin under experimental streptozotocin-induced diabetes mellitus. The study was carried out on laboratory adult white and male rats weighing $180-210 \mathrm{~g}$. The control group consisted of 21 intact animals, and the I experimental group consisted of 21 rats with experimental skin burn injury, experimental II the group consisted of 21 rats without skin burns with experimental streptozotocin-induced diabetes, the III experimental group consisted of 21 rats with skin burn and experimental streptozotocin induced diabetes. The experimental diabetes mellitus model was reproduced by administering rats streptozotocin intradermally once in a dose of $50 \mathrm{mg} / \mathrm{kg}$. Thermal burn skin damage in rats corresponded to II - AB degree - dermal superficial burn (according to the old classification III - A degree) with a total area of $21-23 \%$ of the body surface with the development of burn shock. For morphological studies, a section of the duodenum was taken, fragments of which were processed by conventional methods of light and electron microscopy. The main criteria for assessing damage of the duodenal mucosa were the results of a study comparing histological and ultrastructural data in dynamics after 7, 14 and 21 days after a skin burn. The results of the studies showed a decrease in the number of tight contacts in the intestinal epithelial barrier of the mucous membrane of the duodenum of rats of the first and third experimental groups and the loss of order (the acquisition of a certain randomness) of their localization with increasing time after a burn injury. Defects appear in the intestinal epithelial barrier, which are potential pathways of paracelular translocation of the pathogenic contents of the duodenum. It is possible that part of this intestinal pathogenic content can be translocated and through partially damaged cells. Evidence of the latter is the presence of microbial bodies in the cytoplasm of cells with partially destroyed plasmolemma (but preserved organelles and nucleus). The adaptive mechanism for ensuring the repair of damaged enterocytes is selective autophagy, which acts as a factor in the recycling of the destroyed organelles and cytoplasmic matrix material, primarily aimed at maintaining cell viability. The initiation of autophagy associated with the development of enterocytes stress endoplasmic reticulum (ER-stress). In the enterocytes of the duodenum of rats of the third experimental group, ER-stress occurs so quickly and is accompanied by a steady spread of destruction processes in the cell, autophagy mechanisms do not have time to work, and most cells die. Thus, the absence of an autophagous reaction is a marker of the unfavorable direction of the course of post-burn structural changes in enterocytes.
\end{abstract}

Key words: burn injury, streptozotocin-induced diabetes mellitus, the mucous membrane of the duodenum.

Manuscript is received 12.02.2019

Manuscripted is accepted 19.03.2019 